\title{
FUZZY LOGISTICS MULTICRITERIA DECISION MAKING MODEL FOR FACILITIES LAYOUT
}

\author{
Zedina Lavic, Mugdim Pasic, Branko Vucijak \& Nedzad Dukic
}
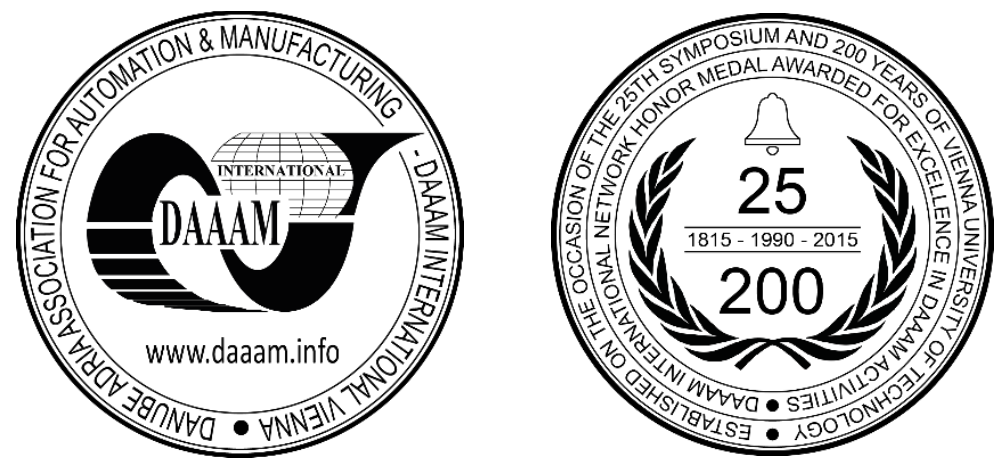

This Publication has to be referred as: Lavic, Z[edina]; Pasic, M[ugdim]; Vucijak, B[ranko] \& Dukic, N[edzad] (2016). Fuzzy Logistics Multicriteria Decision Making Model for Facilities Layout, Proceedings of the 27th DAAAM International Symposium, pp.0650-0657, B. Katalinic (Ed.), Published by DAAAM International, ISBN 978-3-90273408-2, ISSN 1726-9679, Vienna, Austria

DOI: $10.2507 / 27$ th.daaam.proceedings.094

\begin{abstract}
The paper is focused to the facilities layout problem formulated as a problem of fuzzy multicriteria (multi attributive) decision making. The goal is to develop a model for evaluation and selection of solution from Pareto set of solutions (facilities layout alternatives) applying theory for fuzzy sets and fuzzy logic in multicriteria logistics decision.

Decision criteria are selected and grouped according to the logistics objectives, meaning levels of logistics decision making (strategic, tactical and operational level). The decision making problem is structured to decision hierarchy and Fuzzy Analytic Hierarchy process is implemented, which by its essence best corresponds to the problem and the context of decision making, so as to the number and type of selected criteria. The new model is created and tested on a concrete example.
\end{abstract}

Keywords: facilities layout; multicriteria decision making; fuzzy analytic hierarchy process; logistics objectives

\section{Introduction}

The problem of optimizing the layout of facilities has been subject of many researches in the last sixty years. Several recent publications, conferences and researches confirmed the importance of the layout of facilities to meet the requirements set by the market and to achieve the goals of the company [1,2, 3, 4]. The layout of facilities is an important issue not only for production but also for organizations providing services. Since the 1990s, an additional emphasis on this issue came from the strong requirement of the market for mass satisfying of customers in terms of the required product, quantity, variety, place and time of delivery, and this problem is further complicated because of an increase in the degree of uncertainty and ambiguity. Satisfying these demands requires quick reaction and rearrangement of facilities in the shortest possible time and best possible way, in order to reduce costs. The importance of the problem of layout is also reflected by the fact that the costs of material handling, and other costs which depend on the layout, constitute 20$50 \%$ of total operating costs [5]. Requirement to have an efficient process of supply for point of receipt from the point of supply implies the establishment of a logistics system that will allow supply of the right product, in the right condition, at the right time, right place, and at minimum cost. 
Complexity of the logistics system imposes the need for multicriteria optimization and decision-making in order to achieve the basic logistical goal: a smooth flow of goods and information through the system. In order to achieve this goal, it is necessary for the facilities layout to be optimal. The facilities include physical entities such as machines, work centers, production cells, workshops, sections, warehouses and everything else that facilitates achievement of set or expected performances of work. Optimum design of a facility minimizes the costs of handling of the material, the production cycle duration, capital investment, inventories, increases efficiency of work and use of space, safety and comfort of employees, eliminates bottlenecks, enables visual control and maintains flexibility in changing conditions. "Multicriteria optimization can significantly facilitate and accelerate the decision making process"[6].

The facilities layout problem is a point of interest for employees at all levels in the organizational hierarchy. Top management is interested in this problem in terms of the size and efficiency of capital investment. Managers at lower levels are interested in this problem in terms of costs and efficiency of operations, and the workers have interest in terms of safety, comfort, their productivity and earnings.

There are many objectives to be achieved in the making of the facilities layout. They can be shown in the form of functions or in the form of evaluation criteria. According to Langevin and Riopel [7], the objectives of the facilities layout are divided into the following three groups:

- strategic objectives,

- tactical objectives,

- operational objectives.

Due to the complexity of the facilities layout problem, different models used just a few of a large number of layout objectives, and the most commonly used objectives are optimization of the flow (materials, information and personnel), minimization of material handling costs, optimization of equipment use and optimization of capital investment.

The development of fuzzy logic and its application in these models enabled better use of quality objectives (or criteria for the evaluation of the layout alternatives) that are difficult to measure or are difficult to quantify and measure without the use of fuzzy logic (classic).

The facilities layout problem solved in this paper is formulated as a problem of fuzzy multiple criteria (multiple attribute) decision making.

The main objective of this paper is to develop a model for the evaluation and selection of solutions from the Pareto set of solutions (alternatives for layout facilities) using the theory of fuzzy sets and fuzzy logic in multicriteria logistics decision making. The model should also include the criteria (quantitative and qualitative) for strategic, tactical and operational level, which are immanent to the real problems of logistics decision making on the facilities layout, when a decision maker is unable to accurately determine the value of individual criteria or when they are hardly measurable.

\section{Fuzzy logistics multicriteria decision making model forfacilities layout}

The development of the model is implemented through a series of steps:

1. Selection of the decision making criteria

2. Selection of methods for multicriteria decision aid

3. Structuring of the decision making hierarchy

4. Application of the Fuzzy Analytic Hierarchy Process method with checking the consistency of matrices

5. Testing of the model.

\subsection{Decision criteria}

The criteria are selected in accordance with the logistics objectives and they are immanent to real problems of logistics decision making on the facilities layout. It is possible to evaluate the extent to which a certain alternative contributes to achieving the objective referred to each other and to compare alternatives on the basis of criteria (attributes of alternatives). Analogous to division of logistical objectives, the criteria are also divided into 3 groups of criteria:

- Strategic level criteria (12 criteria given in Table 1)

- Tactical level criteria (9 criteria given in Table 2)

- Operational level criteria (9 criteria given in Table 3). 


\begin{tabular}{|c|c|c|c|}
\hline Criteria & Designation & $\begin{array}{l}\text { Unit of } \\
\text { Measure }\end{array}$ & Max/Min \\
\hline $\begin{array}{l}\text { Share of unrealized (unfulfilled) purchase orders (ordered quantity), } \\
\text { caused by lack of capacity, in total ordered quantities per year }\end{array}$ & $\mathrm{SC} 1$ & $\%$ & Min \\
\hline Modularity (plan for future expansion) & $\mathrm{SC} 2$ & $\begin{array}{l}\text { Linguistic } \\
\text { value }\end{array}$ & Max \\
\hline $\begin{array}{l}\text { Consistency with company image, promotional value, public or } \\
\text { community relations }\end{array}$ & $\mathrm{SC} 3$ & $\begin{array}{l}\text { Linguistic } \\
\text { value }\end{array}$ & Max \\
\hline Net present value & SC4 & BAM & Max \\
\hline Internal rate of return & SC5 & $\%$ & Max \\
\hline Payback period & SC6 & $\begin{array}{c}\text { Number of } \\
\text { years }\end{array}$ & Min \\
\hline Installation period & SC7 & $\mathrm{h}$ & Min \\
\hline Noise emission level & SC8 & $\mathrm{dB}$ & Min \\
\hline Quantity of pollutants' emission to the air & SC9 & t/year & Min \\
\hline Quantity of energy used for conditioning, heating and cooling & SC10 & J/year & Min \\
\hline Distance of output / input from the place of loading / unloading & SC11 & $\mathrm{m}$ & Min \\
\hline Total distance of exit from the entrance to other facilities & SC12 & $\mathrm{m}$ & Min \\
\hline
\end{tabular}

Table 1. Strategic level criteria

\begin{tabular}{|c|c|c|c|}
\hline Criteria & Designation & $\begin{array}{l}\text { Unit of } \\
\text { Measure }\end{array}$ & Max/Min \\
\hline Fits into the organizational structure & TC1 & $\begin{array}{l}\text { Linguistic } \\
\text { value }\end{array}$ & Max \\
\hline Facilitating the monitoring, control and communications & TC2 & $\begin{array}{l}\text { Linguistic } \\
\text { value }\end{array}$ & Max \\
\hline Optimizing the use of space & TC3 & $\begin{array}{l}\text { Linguistic } \\
\text { value }\end{array}$ & Max \\
\hline $\begin{array}{l}\text { Number of requests for non-standard elements (equipment, tools, work } \\
\text { surfaces, ...) }\end{array}$ & TC4 & \# & Min \\
\hline Maintain flexibility in scheduling and operations & TC5 & $\begin{array}{l}\text { Linguistic } \\
\text { value }\end{array}$ & Max \\
\hline Average time from service request to service implementation & TC6 & $\mathrm{h}$ & Min \\
\hline $\begin{array}{l}\text { Number of departments in which the intensity of daylight is not } \\
\text { sufficient }\end{array}$ & TC7 & \# & Min \\
\hline Facilitating the maintenance and household & TC8 & $\begin{array}{l}\text { Linguistic } \\
\text { value }\end{array}$ & Max \\
\hline $\begin{array}{l}\text { Distance of departments staffed by employees with disabilities to the } \\
\text { departments with which they are in close cooperation, or restaurant, } \\
\text { toilets }\end{array}$ & TC9 & $\mathrm{m}$ & Min \\
\hline
\end{tabular}

Table 2. Tactical level criteria

\begin{tabular}{|c|c|c|c|}
\hline Criteria & Designation & $\begin{array}{c}\text { Unit of } \\
\text { Measure }\end{array}$ & $\begin{array}{c}\text { Max/ } \\
\text { Min }\end{array}$ \\
\hline „Work in progress“ turnover & OC1 & \# & Max \\
\hline Cost of material flow & $\mathrm{OC} 2$ & BAM & Min \\
\hline Cost of the flow of information and personnel & OC3 & BAM & Min \\
\hline Handling optimization & OC4 & Linguistic value & Max \\
\hline Number of injuries of employees per year & OC5 & $\#$ & Min \\
\hline Number of thefts of materials and equipment per year & OC6 & $\#$ & Min \\
\hline To provide convenience for workers and improve job satisfaction & OC7 & Linguistic value & Max \\
\hline $\begin{array}{l}\text { Percentage of equipment that performs the function in the observed } \\
\text { period }\end{array}$ & OC8 & $\%$ & Max \\
\hline Daily effective engagement of employees & OC9 & $\mathrm{h} /$ day & Max \\
\hline
\end{tabular}

Table 3. Operational level criteria 


\subsection{Selection of multicriteria decision making method}

Due to the complexity of the logistics system and large interdependence of decisions on strategic, tactical and operational level as well as due to number and nature of the criteria imposed by the need to rely on the assessment, Fuzzy Analytic Hierarchy Process is selected and applied as a multicriteria decision making method, which, in its essence is the most appropriate for the problem and the context of decision making. The applied Fuzzy Analytic Hierarchy Process method is based on Chang's fuzzy extent analysis [8]. The basic concept, i.e. hierarchical structure of decision making, pairwise comparison and the bottom up synthesis of priorities through the hierarchy is the same as in classical Analytic Hierarchy Process. The key difference compared to the classical Analytic Hierarchy Process is that with the Fuzzy Analytic Hierarchy Process, decision makers are not required to give strict assessment, but instead, imprecision in the evaluation is allowed.

\subsection{Hierarchy of decision making and model parameters}

The problem of decision making is structured in a hierarchy that has 4 hierarchical levels:

1. Objective: selection of the best alternative from the Pareto set of alternatives for facilities layout

2. Criteria groups

3. Criteria (listed in the criteria groups)

4. Alternatives (Pareto set of alternatives).

The number of alternatives is a variable in the model and the specific parameters of the model are:

1. Number of levels in a hierarchical structure (4),

2. Number of criteria groups (3),

3. Total number of criteria (30),

4. Number of strategic level criteria (12),

5. Number of tactical level criteria (9),

6. Number of operational level criteria (9).

\subsection{Input/output}

Inputs for the model are expert assessments of criteria importance and priorities of alternatives that are entered into pairwise comparison matrices:

1. Pairwise comparison matrix of criteria groups with respect to the objective

2. Pairwise comparison matrix of strategic level criteria with respect to the corresponding group

3. Pairwise comparison matrix of tactical level criteria with respect to the corresponding group

4. Pairwise comparison matrix of operational level criteria with respect to the corresponding group

5. Pairwise comparison matrices of alternatives with respect to each of the criterion.

The outputs of the model are priority values for alternatives sorted from largest to smallest. The best alternative has the highest value of priority.

\subsection{Consistency check}

Pairwise comparison matrices are positive, squared and reciprocal. Elements of matrices are triangular fuzzy numbers from a fuzzy scale obtained through appropriate fuzzification of Saaty's scale [9] in order to derive corresponding classical matrices from the fuzzy matrices and to check the consistency. Consistency of a classical matrix implies consistency of the correspondent fuzzy matrix. Fuzzy scale is shown in Table 4.

\begin{tabular}{|l|c|c|}
\hline \multicolumn{1}{|c|}{ Definition } & Importance intensity & Reciprocals \\
\hline Equal importance & $(1,1,1)$ & $(1,1,1)$ \\
\hline Moderate importance & $(2,3,4)$ & $(1 / 4,1 / 3,1 / 2)$ \\
\hline Strong importance & $(4,5,6)$ & $(1 / 8,1 / 5,1 / 4)$ \\
\hline Very strong importance & $(6,7,8)$ & $(1 / 9,1 / 9,1 / 9)$ \\
\hline Extreme importance & $(9,9,9)$ & $(1 / 3,1 / 2,1),(1 / 5,1 / 4,1 / 3),(1 / 7$, \\
\hline Intermediate values & $(1,2,3),(3,4,5),(5,6,7)$ and & $1 / 6,1 / 5)$ and $(1 / 9,1 / 8,1 / 7)$ \\
\hline
\end{tabular}

Table 4. Fuzzified Saaty's scale 


\subsection{Algorithm model}

The model can be realized through the algorithm whose flowchart is presented in Figure 1.

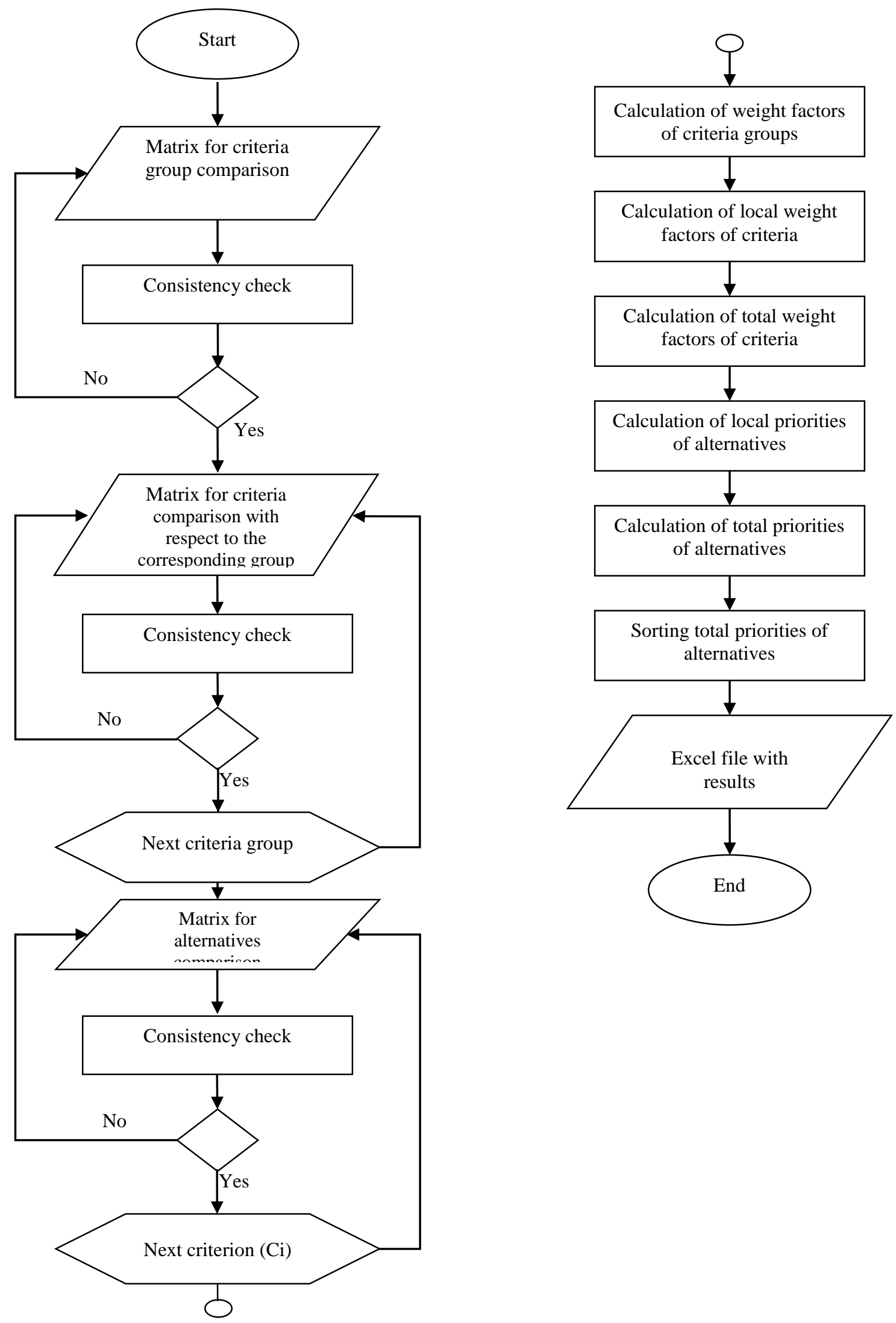

Fig. 1. Flowchart of algorithm model 


\section{Testing model on a concrete example}

The developed model is tested on a concrete example of the selection problem for the best layout alternatives of 3 "workplaces" in a design office, using a Java application made on the basis of the algorithm of the developed model. The facilities here are "workplaces" (desk and chair on an area envisaged to accommodate the movement of the chair when sitting/getting up and working. Layouts of the "workplaces", work desk and floor space envisaged to accommodate furniture and movement of the chair have a form of a rectangle. Layout options (alternatives) from the Pareto set are presented in Figure 2 a-c.

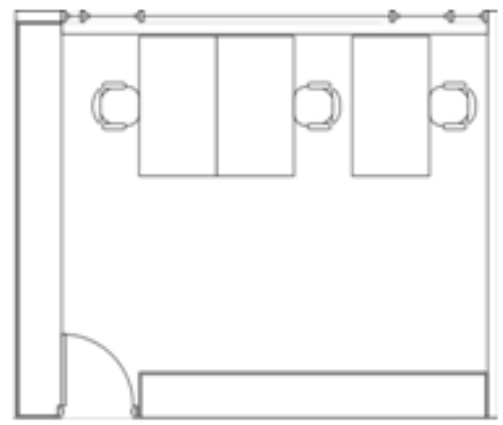

a)

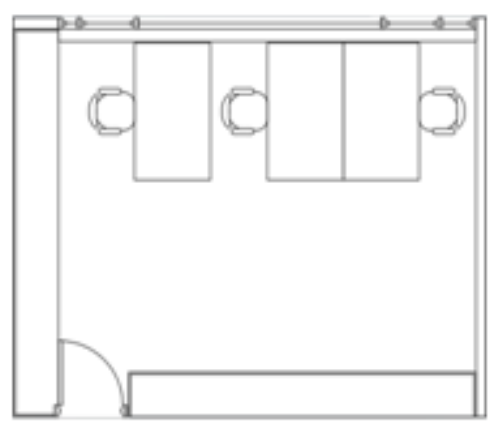

b)

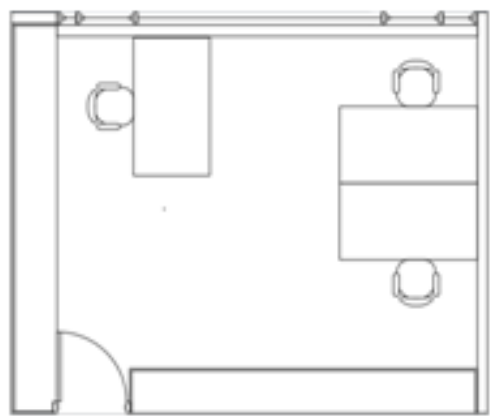

c)

Fig. 2 a) A1, b) A2, c)A3

The decision maker is a sector manager (tactical level) and directly manages the work of employees who will be assigned to "workplaces". Along with the previous explanations of the hierarchical structure of decision making and the use of the Java application, the decision maker made the pairwise comparisons to give assessment of importance of criteria groups with respect to the objective (matrix 1 in Table 1), assessment of criteria importance with respect to the corresponding criteria group (matrices 2-4 in Table 1) and the assessment of the priorities of alternatives with respect to each of the criteria (matrices 5-34 in Table 2). The results are given in Table 7.

\begin{tabular}{|c|c|c|}
\hline Matrix No & Matrix & CR $(\%)$ \\
\hline 1 & {$[(1,1,1)(1 / 3,1 / 2,1)(1 / 3,1 / 2,1)|(1,2,3)(1,1,1)(1,2,3)|(1,2,3)(1 / 3,1 / 2,1)(1,1,1) \mid]$} & 5,23 \\
\hline 2 & $\begin{array}{l}{[(1,1,1)(1,2,3)(1,2,3)(1 / 4,1 / 3,1 / 2)(1 / 3,1 / 2,1)(1 / 3,1 / 2,1)(1 / 5,1 / 4,1 / 3)(1,1,1)(1,1,1)} \\
(1 / 5,1 / 4,1 / 3)(1 / 3,1 / 2,1)(1 / 3,1 / 2,1) \mid(1 / 3,1 / 2,1)(1,1,1)(1 / 3,1 / 2,1)(2,3,4)(1,1,1)(1,1,1) \\
(1,2,3)(2,3,4)(1,1,1)(1,1,1)(1,2,3)(3,4,5) \mid(1 / 3,1 / 2,1)(1,2,3)(1,1,1)(1 / 3,1 / 2,1)(1 / 3, \\
1 / 2,1)(1 / 3,1 / 2,1)(1,1,1)(1,1,1)(1,1,1)(1,2,3)(1,2,3)(1,2,3) \mid(2,3,4)(1 / 4,1 / 3,1 / 2)(1, \\
2,3)(1,1,1)(1 / 4,1 / 3,1 / 2)(1 / 4,1 / 3,1 / 2)(1,1,1)(1,1,1)(1,1,1)(1,1,1)(1,1,1)(1,2,3) \mid(1, \\
2,3)(1,1,1)(1,2,3)(2,3,4)(1,1,1)(1,1,1)(1,2,3)(2,3,4)(1,1,1)(1,1,1)(1,2,3)(2,3,4) \\
\mid(1,2,3)(1,1,1)(1,2,3)(2,3,4)(1,1,1)(1,1,1)(1,2,3)(2,3,4)(1,1,1)(1,1,1)(1,2,3)(2, \\
3,4) \mid(3,4,5)(1 / 3,1 / 2,1)(1,1,1)(1,1,1)(1 / 3,1 / 2,1)(1 / 3,1 / 2,1)(1,1,1)(1,2,3)(1,1,1)(1, \\
1,1)(1,2,3)(2,3,4) \mid(1,1,1)(1 / 4,1 / 3,1 / 2)(1,1,1)(1,1,1)(1 / 4,1 / 3,1 / 2)(1 / 4,1 / 3,1 / 2)(1 / 3, \\
1 / 2,1)(1,1,1)(1 / 4,1 / 3,1 / 2)(1,1,1)(1,1,1)(2,3,4) \mid(1,1,1)(1,1,1)(1,1,1)(1,1,1)(1,1,1) \\
(1,1,1)(1,1,1)(2,3,4)(1,1,1)(1,1,1)(1,2,3)(2,3,4) \mid(3,4,5)(1,1,1)(1 / 3,1 / 2,1)(1,1,1) \\
(1,1,1)(1,1,1)(1,1,1)(1,1,1)(1,1,1)(1,1,1)(1,2,3)(2,3,4) \mid(1,2,3)(1 / 3,1 / 2,1)(1 / 3,1 / 2, \\
1)(1,1,1)(1 / 3,1 / 2,1)(1 / 3,1 / 2,1)(1 / 3,1 / 2,1)(1,1,1)(1 / 3,1 / 2,1)(1 / 3,1 / 2,1)(1,1,1)(1,1,1) \mid \\
(1,2,3)(1 / 5,1 / 4,1 / 3)(1 / 3,1 / 2,1)(1 / 3,1 / 2,1)(1 / 4,1 / 3,1 / 2)(1 / 4,1 / 3,1 / 2)(1 / 4,1 / 3,1 / 2)(1 / 4,1 / 3, \\
1 / 2)(1 / 4,1 / 3,1 / 2)(1 / 4,1 / 3,1 / 2)(1,1,1)(1,1,1) \mid]\end{array}$ & 7,96 \\
\hline
\end{tabular}




\begin{tabular}{|c|c|c|}
\hline Matrix No & Matrix & CR (\%) \\
\hline 3 & $\begin{array}{l}{[(1,1,1)(1,1,1)(1,2,3)(2,3,4)(1,2,3)(1,1,1)(1,1,1)(1,2,3)(1,1,1) \mid(1,1,1)(1,1,1)} \\
(1,1,1)(1,2,3)(1,2,3)(1,1,1)(1,1,1)(1,2,3)(1,1,1) \mid(1 / 3,1 / 2,1)(1,1,1)(1,1,1)(1,1,1) \\
(1,1,1)(1,1,1)(1,1,1)(1,1,1)(1,1,1) \mid(1 / 4,1 / 3,1 / 2)(1 / 3,1 / 2,1)(1,1,1)(1,1,1)(1,1,1)(1, \\
1,1)(1,1,1)(1,1,1)(1,1,1) \mid(1 / 3,1 / 2,1)(1 / 3,1 / 2,1)(1,1,1)(1,1,1)(1,1,1)(1,1,1)(1,1,1) \\
(1,1,1)(1,1,1)|(1,1,1)(1,1,1)(1,1,1)(1,1,1)(1,1,1)(1,1,1)(1,1,1)(1,1,1)(1,1,1)| \\
(1,1,1)(1,1,1)(1,1,1)(1,1,1)(1,1,1)(1,1,1)(1,1,1)(1,1,1)(1,1,1) \mid(1 / 3,1 / 2,1)(1 / 3,1 / 2, \\
1)(1,1,1)(1,1,1)(1,1,1)(1,1,1)(1,1,1)(1,1,1)(1,1,1) \mid(1,1,1)(1,1,1)(1,1,1)(1,1,1) \\
(1,1,1)(1,1,1)(1,1,1)(1,1,1)(1,1,1) \mid]\end{array}$ & 1,67 \\
\hline 4 & $\begin{array}{l}{[(1,1,1)(1 / 3,1 / 2,1)(1 / 3,1 / 2,1)(1 / 3,1 / 2,1)(1 / 3,1 / 2,1)(1 / 3,1 / 2,1)(1 / 4,1 / 3,1 / 2)(1,1,1)(1,1,} \\
1)|(1,2,3)(1,1,1)(1,1,1)(1,1,1)(1,1,1)(2,3,4)(2,3,4)(2,3,4)(2,3,4)|(1,2,3)(1,1, \\
1)(1,1,1)(1,1,1)(1,1,1)(2,3,4)(2,3,4)(2,3,4)(2,3,4) \mid(1,2,3)(1,1,1)(1,1,1)(1,1,1) \\
(1,1,1)(1,2,3)(2,3,4)(3,4,5)(1,1,1) \mid(1,2,3)(1,1,1)(1,1,1)(1,1,1)(1,1,1)(1,1,1)(1, \\
2,3)(2,3,4)(3,4,5) \mid(1,2,3)(1 / 4,1 / 3,1 / 2)(1 / 4,1 / 3,1 / 2)(1 / 3,1 / 2,1)(1,1,1)(1,1,1)(1,1,1) \\
(1,1,1)(2,3,4) \mid(2,3,4)(1 / 4,1 / 3,1 / 2)(1 / 4,1 / 3,1 / 2)(1 / 4,1 / 3,1 / 2)(1 / 3,1 / 2,1)(1,1,1)(1,1,1) \\
(1,1,1)(1 / 4,1 / 3,1 / 2) \mid(1,1,1)(1 / 4,1 / 3,1 / 2)(1 / 4,1 / 3,1 / 2)(1 / 5,1 / 4,1 / 3)(1 / 4,1 / 3,1 / 2)(1,1,1) \\
(1,1,1)(1,1,1)(1,2,3) \mid(1,1,1)(1 / 4,1 / 3,1 / 2)(1 / 4,1 / 3,1 / 2)(1,1,1)(1 / 5,1 / 4,1 / 3)(1 / 4,1 / 3,1 / 2) \\
(2,3,4)(1 / 3,1 / 2,1)(1,1,1) \mid]\end{array}$ & 6,75 \\
\hline
\end{tabular}

Table 5. Pairwise comparison matrices $1-4$

\begin{tabular}{|c|c|c|}
\hline Matrix No & Matrix & $\mathbf{C R}(\%)$ \\
\hline 5 & 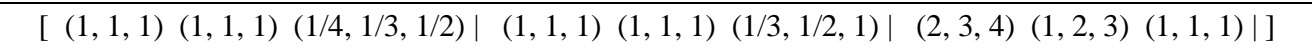 & 1,92 \\
\hline 6 & {$[(1,1,1)(1,1,1)(1 / 5,1 / 4,1 / 3)|(1,1,1)(1,1,1)(1 / 5,1 / 4,1 / 3)|(3,4,5)(3,4,5)(1,1,1) \mid]$} & 0,00 \\
\hline 7 & {$[(1,1,1)(1,1,1)(2,3,4)|(1,1,1)(1,1,1)(2,3,4)|(1 / 4,1 / 3,1 / 2)(1 / 4,1 / 3,1 / 2)(1,1,1) \mid]$} & 0,00 \\
\hline 8 & {$[(1,1,1)(1,1,1)(1,1,1)|(1,1,1)(1,1,1)(1,2,3)|(1,1,1)(1 / 3,1 / 2,1)(1,1,1) \mid]$} & 4,79 \\
\hline 9 & $\begin{array}{l}(1,1,1)(1,1,1)(1,1,1)|(1,1,1)(1,1,1)(1,2,3)|(1,1,1)(1 / 3,1 / 2,1)(1,1,1) \mid] \\
\end{array}$ & 4,79 \\
\hline 10 & $\begin{array}{l}(1,1,1)(1,1,1)(1,1,1)|(1,1,1)(1,1,1)(1,2,3)|(1,1,1)(1 / 3,1 / 2,1)(1,1,1) \mid] \\
\end{array}$ & 4,79 \\
\hline 11 & 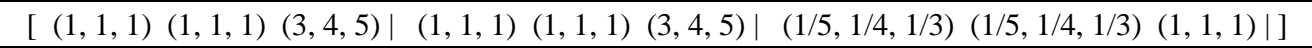 & 0,00 \\
\hline 12 & {$[(1,1,1)(1,1,1)(1,1,1)|(1,1,1)(1,1,1)(1 / 3,1 / 2,1)|(1,1,1)(1,2,3)(1,1,1) \mid]$} & 4,79 \\
\hline 13 & {$[(1,1,1)(1,1,1)(1,1,1)|(1,1,1)(1,1,1)(1 / 3,1 / 2,1)|(1,1,1)(1,2,3)(1,1,1) \mid]$} & 4,79 \\
\hline 14 & {$[(1,1,1)(1,1,1)(1,1,1)|(1,1,1)(1,1,1)(1,2,3)|(1,1,1)(1 / 3,1 / 2,1)(1,1,1) \mid]$} & 4,79 \\
\hline 15 & 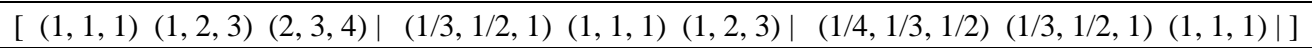 & 0,96 \\
\hline 16 & {$[(1,1,1)(1,2,3)(2,3,4)|(1 / 3,1 / 2,1)(1,1,1)(1,2,3)|(1 / 4,1 / 3,1 / 2)(1 / 3,1 / 2,1)(1,1,1) \mid]$} & 0,96 \\
\hline 17 & {$[(1,1,1)(1,1,1)(1,2,3)|(1,1,1)(1,1,1)(1,2,3)|(1 / 3,1 / 2,1)(1 / 3,1 / 2,1)(1,1,1) \mid]$} & 0,00 \\
\hline 18 & {$[(1,1,1)(1,1,1)(2,3,4)|(1,1,1)(1,1,1)(1,2,3)|(1 / 4,1 / 3,1 / 2)(1 / 3,1 / 2,1)(1,1,1) \mid]$} & 1,78 \\
\hline 19 & 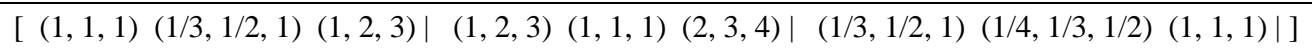 & 0,96 \\
\hline 20 & $\begin{array}{l}{[(1,1,1)(1,1,1)(3,4,5)|(1,1,1)(1,1,1)(3,4,5)|(1 / 5,1 / 4,1 / 3)(1 / 5,1 / 4,1 / 3)(1,1,1) \mid]} \\
\end{array}$ & 0,00 \\
\hline 21 & {$[(1,1,1)(1,1,1)(1 / 3,1 / 2,1)|(1,1,1)(1,1,1)(1 / 3,1 / 2,1)|(1,2,3)(1,2,3)(1,1,1) \mid]$} & 0,00 \\
\hline 22 & $\begin{array}{c}(1,1,1)(1 / 3,1 / 2,1)(2,3,4)|(1,2,3)(1,1,1)(2,3,4)|(1 / 4,1 / 3,1 / 2)(1 / 4,1 / 3,1 / 2)(1,1,1) \mid \\
\end{array}$ & 5,64 \\
\hline 23 & 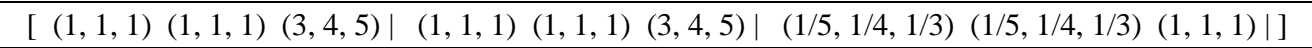 & 0,00 \\
\hline 24 & 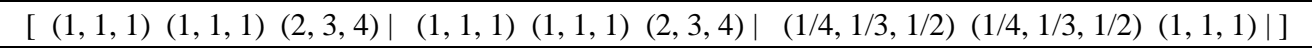 & 0,00 \\
\hline 25 & {$[(1,1,1)(1,1,1)(1,2,3)|(1,1,1)(1,1,1)(1,2,3)|(1 / 3,1 / 2,1)(1 / 3,1 / 2,1)(1,1,1) \mid]$} & 0,00 \\
\hline 26 & {$[(1,1,1)(1,1,1)(1,2,3)|(1,1,1)(1,1,1)(1,2,3)|(1 / 3,1 / 2,1)(1 / 3,1 / 2,1)(1,1,1) \mid]$} & 0,00 \\
\hline 27 & {$[(1,1,1)(1,1,1)(1,2,3)|(1,1,1)(1,1,1)(1,2,3)|(1 / 3,1 / 2,1)(1 / 3,1 / 2,1)(1,1,1) \mid]$} & 0,00 \\
\hline 28 & {$[(1,1,1)(1,1,1)(2,3,4)|(1,1,1)(1,1,1)(2,3,4)|(1 / 4,1 / 3,1 / 2)(1 / 4,1 / 3,1 / 2)(1,1,1) \mid]$} & 0,00 \\
\hline 29 & {$[(1,1,1)(1,1,1)(2,3,4)|(1,1,1)(1,1,1)(1,2,3)|(1 / 4,1 / 3,1 / 2)(1 / 3,1 / 2,1)(1,1,1) \mid]$} & 1,78 \\
\hline 30 & {$[(1,1,1)(1,1,1)(3,4,5)|(1,1,1)(1,1,1)(3,4,5)|(1 / 5,1 / 4,1 / 3)(1 / 5,1 / 4,1 / 3)(1,1,1) \mid]$} & 0,00 \\
\hline 31 & {$[(1,1,1)(1,2,3)(2,3,4)|(1 / 3,1 / 2,1)(1,1,1)(1,2,3)|(1 / 4,1 / 3,1 / 2)(1 / 3,1 / 2,1)(1,1,1) \mid]$} & 0,96 \\
\hline 32 & 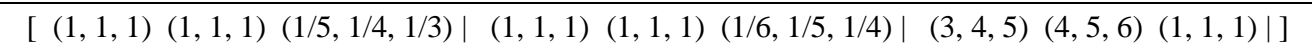 & 0,75 \\
\hline 33 & {$[(1,1,1)(1,1,1)(1,2,3)|(1,1,1)(1,1,1)(1,2,3)|(1 / 3,1 / 2,1)(1 / 3,1 / 2,1)(1,1,1) \mid]$} & 0,00 \\
\hline 34 & {$[(1,1,1)(1,1,1)(4,5,6)|(1,1,1)(1,1,1)(4,5,6)|(1 / 6,1 / 5,1 / 4)(1 / 6,1 / 5,1 / 4)(1,1,1) \mid]$} & 0,00 \\
\hline
\end{tabular}

Table 6. Pairwise comparison matrices 5-34 


\begin{tabular}{|c|c|c|}
\hline Alternative & Fuzzy AHP & Clasical AHP \\
\hline A 1 & 0,4262 & 0,3868 \\
\hline A 2 & 0,4244 & 0,3962 \\
\hline A 3 & 0,1492 & 0,2168 \\
\hline
\end{tabular}

Table 7. Results

According to Fuzzy Analytic Hierarchy Process the best alternative is A1, while according to classical Analytic Hierarchy Process the best alternative is A2. Result (A1) is the expected.

\section{Conclusion}

In this paper facilities layout problem formulated as a problem of fuzzy multicriteria (multi attributive) decision making is solved and a model for evaluation and selection of solution from Pareto set of solutions (facilities layout alternatives) applying theory for fuzzy sets and fuzzy logic in multicriteria logistics decision is developed. The proposed fuzzy model for logistics multicriteria decision making on the facilities layout, developed on the basis of systemic thinking and a holistic approach to solving logistics problems, includes a relatively large number of criteria (quantitative and qualitative) is applicable in situations where it is difficult to measure criteria or it is difficult to quantify and measure them without the application of fuzzy logic.

Compared to models based on the classic Analytic Hierarchy Process method, the advantage of the proposed model based on the Fuzzy Analytic Hierarchy Process method is reflected in the fact that the expert assessments expressed verbally do not appear as strict assessments, but as to some extent overlapping normal, convex fuzzy sets (triangular fuzzy numbers) that are a more realistic presentation of expert assessments of the relative importance of the criteria and the relative priority of alternatives.

Future research can be carried out to the direction of integration of the proposed model for multicriteria decision making with models for the generation of facilities layout alternatives and to the direction of the modification of the model for team decision-making.

\section{References}

[1] Yang L., Deuse J. (2012): Multiple-attribute Decision Making for an Energy Efficient Facility Layout Design, Procedia CIRP, Vol 3, Pages 149-154, 45 ${ }^{\text {th }}$ CIRP Conference on Manufacturing Systems 2012

[2] Karande P., Chakraborty S.: A Facility Layout Selection Model using MACBETH Method, Proceedings of the 2014 International Conference on Industrial Engineering and Operations Management Bali, Indonesia, January 7-9, 2014.

[3] Bacudio L, Esmeria G. J., Promentilla M. A.: A Fuzzy Analytic Hierarchy Process Approach for Optimal Selection of Manufacturing Layout, Presented at the DLSU Research Congress 2016, De La Salle University, Manila, Philippines, March 7-9, 2016.

[4] Shokri H., Ashjari B., Saberi M., Yoon J. H (2013): An Integrated AHP-VIKOR Methodology for Facility Layout Design, Industrial Engineering \& Management Systems, Vol 12, No 4, December 2013

[5] Tompkins J A., White J. A., Bozer Y. A. \& Tanchoco, J. M. A.: Facilities Planning, 4th Edition, John Wiley \& Sons, Inc, USA, 2010.,

[6] Vucijak, B., Pasic, M. \& Zorlak, AJ. (2015). Use of Multi-criteria Decision Aid Methods for Selection of the Best Alternative for the Highway Tunnel Doors, 25th DAAAM International Symposium on Intelligent Manufacturing and Automation, DAAAM 2014, Procedia Engineering, Vol. 100, (2015), pp. 656-665

[7] Langevin A., Riopel D. (2005): Logistics Systems: Design and Optimization, Springer Science + Business Media, New York

[8] Kahraman, C. (2008) Fuzzy Multi-Criteria Decision Making, Theory and Applications with Recent Developments, New Jork, Springer Science+Business Media, LLC.

[9] Saaty, T. L. (1980), Analytic hierarchy process, New York, McGraw-Hill 